RESEARCH ARTICLE

\title{
EFFECTS OF BOTTOM ASH AND COW MANURE COMPOST ON CHEMICAL PROPERTIES OF SOIL AT NEW-ESTABLISHED RICE FIELD
}

\author{
Nurmegawati*, Iskandar, and Sudarsono \\ Department of Soil Science and Land Resources, Faculty of Agriculture, \\ Bogor Agricultural University, Bogor, Indonesia \\ Submitted: 2018-07-26 Accepted: 2018-11-16
}

\begin{abstract}
The conversion of dryland to rice field at Sumatra Island, Indonesia was generally developed on marginal lands with Ultisols and Oxisols soil types. Those soil types contained high iron (Fe) and aluminum (Al), but low phosphorus (P) and potassium (K). That is because the changes in the process resulted from submerging the soil. For example, the decrease of redox potential, ion reduction from $\mathrm{Fe}^{3+}$ to $\mathrm{Fe}^{2+}$, and $\mathrm{Mn}^{4+}$ into $\mathrm{Mn}^{2+}$. Those compounds will be dissolved and can be absorbed by plants thus causing toxicity. The objective of the study was to assess the effects of bottom ash and cow manure compost at the various doses on soil chemical properties and rice yield on the new-established rice field. This research used factorial design with two factors in Completely Randomized Design. The factors were a dose of bottom ash and cow manure compost, with three replications. The results showed. The addition of bottom ash and cow manure compost at the dosage in this study was not able to reduce the levels of FeDTPA and MnDTPA at newly established rice fields. However, the application of cow manure compost significantly increased soil $\mathrm{pH}$, exchangeable cation $(\mathrm{K}, \mathrm{Na}, \mathrm{Ca})$, base saturation and decreased exchangeable- $\mathrm{H}$. The addition of bottom ash does not affect paddy yield, while cow manure compost up to 10 tons ha ${ }^{-1}$ increased panicle and straw dry weight.
\end{abstract}

Keywords: new-established rice field, bottom ash, cow manure compost, chemical properties

How to Cite: Nurmegawati, Iskandar, and Sudarsono. (2019). Effect of Bottom Ash and Cow Manure Compost on Chemical Properties of Soil at New-Established Rice Field. Sains Tanah Journal of Soil Science and Agroclimatology, 16(1): 1-12 (doi: 10.20961/stjssa.v16i1.22366)

Permalink/DOI: http://dx.doi.org/10.20961/stjssa.v16i1.22366

\section{INTRODUCTION}

Food demand, especially rice, will continue to increase in line with the increase of population, so the Indonesian government is trying to increase rice production. One of the opportunities that will contribute substantially to future rice production growth is the opening of new paddy fields. The development of paddy fields of new openings from drylands at Sumatra island is generally on marginal lands

\footnotetext{
* Corresponding Author :
}

Email: nurmegawati400@gmail.com with Ultisols and Oxisols, which contained high levels of $\mathrm{Fe}$ and $\mathrm{Al}$ with $\mathrm{P}$ and $\mathrm{K}$ deficiencies. (Hartatik et al., 2010) stated that rice crops were grown in new openings in Lampung, South Sumatra, Jambi, Riau, West Sumatra and Bengkulu generally have Fe toxicity.

The problems of the new opening lands were the changes in chemical properties as a result of flooding, such as: (1) the decrease of redox potential and (2) the reduction of $\mathrm{Fe}^{3+}$ into $\mathrm{Fe}^{2+}$ and $\mathrm{Mn}^{4+}$ into $\mathrm{Mn}^{2+}$ which are dissolved and can be absorbed by plants causing toxic (Nursyamsi et al., 1996). 
The Fe-toxic soil at new-established rice field leads to low production or even crop failure. According to (Hartatik et al., 2010) changes in soil chemical properties on marginal lands that are newly planted into potential paddy fields in Indonesia generally take up to 5 years, depending on the level of irrigation, soil iron content, and land management by farmers. Without proper management, the new opening will be stable after 10-15 years.

The new-established rice field in Sitiung, Dharmasraya Regency with Ultisol soil type was classified as infertile soil, which are characterized base saturation $15.46 \%$ (very low) Cation Exchangeable Capacity 15.20 me/100g (low), Organic Carbon 1.99\% (low) and available $\mathrm{P} 4.63 \mathrm{ppm}$ (low), Al saturation $49.89 \%$ (high) , Fe extract with $1 \mathrm{M} \mathrm{CH}_{3} \mathrm{COONa}$ $\mathrm{pH} 2,857.32 \mathrm{ppm}$ (very high), and likely to cause iron toxicity (Herviyanty et al., 2011). In addition, there was a change of redox potential become very low or negative, that will affect $\mathrm{pH}, \mathrm{Fe}$ and another nutrients availability (Hartatik et al., 2010). To solve this problem, the action to repair soil condition, called the amelioration is important to support the optimal growth of rice.

Coal ash, which is in the form of a fly and bottom ash is very potential to be used as ameliorant because its availability is quite a lot as waste. According to Sell et al. (1989) the bottom ash was useful for ameliorant without adverse effects on soil, plants, and environment. Agustini (2016) adds that the bottom ash on acid minerals did not cause the heavy metals adsorption in choy sum (Brassica juncea) to rise or higher than the threshold. According to Park et al. (2012) bottom ash contains macronutrients $(\mathrm{P}, \mathrm{K}, \mathrm{Ca}, \mathrm{Mg}, \mathrm{S})$ and microelements ( $\mathrm{Fe}, \mathrm{Mn}, \mathrm{Zn}, \mathrm{Cu}$ ) which can be used for plant growth. This was supported by James et al. (2012) that the bottom ash has the potential to be a fixer and plant growth medium for fertilizing and neutralizing soil acidity.

Based on Iskandar at al. (2008) the addition bottom ash can increase the soil $\mathrm{pH}$ and the availability of base cations in peat soils. Agustini (2016) showed that bottom ash increased the $\mathrm{pH}$, total $\mathrm{N}$, available $\mathrm{P}$ and exchangeable cations ( $\mathrm{K}, \mathrm{Na}, \mathrm{Ca}$ and $\mathrm{Mg}$ ), increase crop growth and yield, also the $N, P, K$, $\mathrm{Ca}, \mathrm{Mg}$ contents in choy sum. Cow manure compost can improve soil physical, chemical, and biological properties. Tan (1998) stated that the addition of organic material on soils containing excessive and dissolved $\mathrm{Fe}$ and $\mathrm{Mn}$ elements will form complexes. Utami \& Handayani (2003) stated the presence of organic compounds allows the occurrence of chelate by binding the metal cations such as Fe and $\mathrm{Mn}$. This is to reduce the binding of phosphate by $\mathrm{Fe} / \mathrm{Al}$ oxide and silicate clay so that $\mathrm{P}$ becomes available.

The addition of bottom ash and cow manure compost is expected to overcome the problems in a new-established rice field, especially the chemical properties. The purpose of this research is to study the effects of bottom ash and cow manure compost at various doses on soil chemical properties and rice yield at new-established rice field.

\section{MATERIALS AND METHODS}

The materials used in this study were the coal bottom ash obtained from the landfill of Paiton power plant, cow manure compost, rice seed, and soil samples of Oxisols taken from Gunung Sindur, Bogor. The chemical properties of Oxisols soil for rice planting media are presented in Table 1.

A pot experiment was conducted in a greenhouse using Completely Randomized Design (CRD) with two factors and three replications. The first factor was a dose of bottom ash $\left(0,1,2.5\right.$, and 5 tons ha $\left.{ }^{-1}\right)$, while the second factor was a dose of cow manure. The 
chemical characteristics of the bottom ash and cow manure compost are presented in Table 3 and 4. Each experiment was repeated three times so that overall there were 36 experimental pots. The treatments for experiments in greenhouses are presented in Table 2.

Oxisols soil material weighing $8 \mathrm{~kg}$ of air dry put into a bucket and given water and stirred evenly using wood with the purpose of lubrication for 10 days, stirring is done repeatedly so that the soil really has a condition similar to paddy soil. Furthermore, ameliorant materials are mixed with the growing media until homogeneous and then incubated for 7 days. Ready-to-plant rice seedlings were selected in a homogeneous manner by seeing the height and number of leaves, then the seedlings were transplanted on media, three plants for each pot. After that, the drainage begins at intervals of 1 week, with a height of $3 \mathrm{~cm}$ of water from the ground and then drained. Next, fertilization, weeding, controlling plant pests, harvesting organisms and watering were conducted.

Table 1. Initial soil chemical properties (Oxisols)

\begin{tabular}{|c|c|c|c|}
\hline Parameter & Unit & Value & Determination Method/Measuring Device \\
\hline $\mathrm{pH}$ & - & 4.01 & $\mathrm{pH}$ meter \\
\hline Organic-C & $\%$ & 2.7 & Walkley \& Black \\
\hline Total-P & $\mathrm{mg} \mathrm{P}_{2} \mathrm{O}_{5} 100^{-1} \mathrm{~g}^{-1}$ & 33.2 & Extracted with $\mathrm{HCl}$ \\
\hline Available-P & $\mathrm{ppm}$ & 1.0 & Bray 1 \\
\hline Fe-dithionite & $\%$ & 0.87 & Extract Dithionite-citrate \\
\hline Fe-oxalate & $\%$ & 0.58 & Extract Ammonium Oxalate $0,2 \mathrm{M} \mathrm{pH} 3$ \\
\hline $\mathrm{Fe}_{\text {DTPA }}$ & $\mathrm{ppm}$ & 58.3 & Extract DTPA \\
\hline$M n_{D T P A}$ & ppm & 372 & Extract DTPA \\
\hline Exchangeable-Al & $\mathrm{cmol}(+) \mathrm{kg}^{-1}$ & 1.2 & $\mathrm{KCl} 1 \mathrm{~N}$ \\
\hline Exchangeable-H & $\mathrm{cmol}(+) \mathrm{kg}^{-1}$ & 0.3 & $\mathrm{KCl} 1 \mathrm{~N}$ \\
\hline CEC & $\mathrm{cmol}(+) \mathrm{kg}^{-1}$ & 18.4 & Extracted with $\mathrm{NH}_{4} \mathrm{OAC} 1 \mathrm{~N} \mathrm{pH} 7$ \\
\hline Exchangeable-Ca & $\mathrm{cmol}(+) \mathrm{kg}^{-1}$ & 1.4 & Extracted with $\mathrm{NH}_{4} \mathrm{OAC} 1 \mathrm{~N} \mathrm{pH} 7$ \\
\hline Exchangeable-Mg & $\mathrm{cmol}(+) \mathrm{kg}^{-1}$ & 0.4 & Extracted with $\mathrm{NH}_{4} \mathrm{OAC} 1 \mathrm{~N} \mathrm{pH} 7$ \\
\hline Exchangeable-Na & $\mathrm{cmol}(+) \mathrm{kg}^{-1}$ & 0.1 & Extracted with $\mathrm{NH}_{4} \mathrm{OAC} 1 \mathrm{~N} \mathrm{pH} 7$ \\
\hline Exchangeable-K & $\mathrm{cmol}(+) \mathrm{kg}^{-1}$ & 0.3 & Extracted with $\mathrm{NH}_{4} \mathrm{OAC} 1 \mathrm{~N} \mathrm{pH} 7$ \\
\hline Base saturation & $\%$ & 11.9 & - \\
\hline
\end{tabular}

Table 2. Combination of doses of bottom ash $(A)$ and cow manure compost $(K)$

\begin{tabular}{ccc}
\hline Treatment & Doses of bottom ash $\left(\mathrm{gram} \mathrm{pot}^{-\mathbf{1}}\right)$ & Doses of cow manure compost $\left(\mathrm{gram} \mathrm{pot}^{\mathbf{- 1}}\right)$ \\
\hline A0K0 & 0 & 0 \\
AOK1 & 0 & 20 \\
AOK2 & 0 & 40 \\
A1K0 & 4 & 0 \\
A1K1 & 4 & 20 \\
A1K2 & 4 & 40 \\
A2K0 & 10 & 0 \\
A2K1 & 10 & 20 \\
A2K2 & 10 & 40 \\
A3K0 & 20 & 0 \\
A3K1 & 20 & 20 \\
A3K2 & 20 & 40 \\
\hline
\end{tabular}


Table 3. Chemical characteristics of the bottom ash *)

\begin{tabular}{lll}
\hline Parameter & Unit & Value \\
\hline $\mathrm{pH} \mathrm{H}_{2} \mathrm{O}$ & - & 6.60 \\
$\mathrm{SiO}_{2}$ & $\%$ & 57.8 \\
$\mathrm{Al}_{2} \mathrm{O}_{3}$ & $\%$ & 13.79 \\
$\mathrm{Fe}_{2} \mathrm{O}_{3}$ & $\%$ & 16.93 \\
$\mathrm{~K}_{2} \mathrm{O}$ & $\%$ & 1.38 \\
$\mathrm{Na}_{2} \mathrm{O}$ & $\%$ & 0.26 \\
$\mathrm{CaO}$ & $\%$ & 4.83 \\
$\mathrm{MgO}$ & $\%$ & 2.43 \\
$\mathrm{TiO}_{2}$ & $\%$ & 1.03 \\
$\mathrm{MnO}$ & $\%$ & 0.10 \\
$\mathrm{P}_{2} \mathrm{O}_{5}$ & $\%$ & 0.026 \\
\hline
\end{tabular}

*) Source : Agustini (2016)

Table 4. Characteristics of cow manure compost *)

\begin{tabular}{lll}
\hline Parameter & Method & Value \\
\hline Water contect (\%) & Gravimetri & 23.74 \\
C-total (\%) & CNS-Analyzer & 12.80 \\
$\mathrm{~N}$-total (\%) & CNS-Analyzer & 1.53 \\
$\mathrm{C} / \mathrm{N}$ ratio & - & 8 \\
$\mathrm{P}_{2} \mathrm{O}_{5}$-total (\%) & $\mathrm{HNO}_{3} /$ Spectrophotometer & 0.78 \\
$\mathrm{~K}{ }_{2} \mathrm{O}$ total (\%) & $\mathrm{HNO}_{3} / \mathrm{FAAS}$ & 1.13 \\
Exchangeable $-\mathrm{K}\left(\mathrm{cmol}(+) \mathrm{kg}^{-1}\right)$ & $\mathrm{NH}_{4} \mathrm{OAc} \mathrm{pH} \mathrm{7}$ & 16.31 \\
Exchangeable $-\mathrm{Na}\left(\mathrm{cmol}(+) \mathrm{kg}^{-1}\right)$ & $\mathrm{NH}_{4} \mathrm{OAc} \mathrm{pH} \mathrm{7}$ & 5.21 \\
Exchangeable $-\mathrm{Ca}\left(\mathrm{cmol}(+) \mathrm{kg}^{-1}\right)$ & $\mathrm{NH}_{4} \mathrm{OAc} \mathrm{pH} \mathrm{7}$ & 19.66 \\
Exchangeable $-\mathrm{Mg}\left(\mathrm{cmol}(+) \mathrm{kg}^{-1}\right)$ & $\mathrm{NH}_{4} \mathrm{OAc} \mathrm{pH} \mathrm{7}$ & 9.14 \\
\hline
\end{tabular}

*) Source : Agustini (2016)

The soil properties observed during plant growth were redox potential (Eh) and $\mathrm{pH}$ ( $\mathrm{pH}$-meter), $\mathrm{Fe}$ and $\mathrm{Mn}$ contents in water, $\mathrm{Fe}_{\text {DTPA, }}$ and $\mathrm{Mn}_{\text {DTPA }}$ in the soil. After harvest, soil $\mathrm{pH}$ (pH-meter), exchangeable-H ( $\mathrm{KCl} 1 \mathrm{M}), \mathrm{CEC}$ ( $\mathrm{NH}_{4} \mathrm{OAc} 1 \mathrm{~N} \mathrm{pH} 7$ ), exchangeable-Ca, $-\mathrm{Mg},-\mathrm{K},-$ $\mathrm{Na}\left(\mathrm{NH}_{4} \mathrm{OAc} 1 \mathrm{~N} \mathrm{pH} 7\right.$ extraction, $\mathrm{K}$ and $\mathrm{Ca}$ measured using flame photometer, $\mathrm{Ca}$ and $\mathrm{Mg}$ measured using ASS), Fe and Mn (DTPA extraction, measured using ASS) were observed. Crop growth and yield parameters observed were the numbers, length, and weight of panicles; pithy rice and dry straw weight. The data were analyzed using Analysis of Variance (ANOVA) and further testing using Duncan's Multiple Range Test (DMRT) at 5\% significance level.

\section{RESULTS}

The Fluctuation of Soil Eh and $\mathrm{pH}$, exchangeable-Fe and $-\mathrm{Mn}$ in water solution, $\mathrm{Fe}_{D T P A}$, and $\mathrm{Mn}_{\mathrm{DTPA}}$ during plant growth

The redox potential (Eh) is the soil chemical properties first changed by flooding. The effect of the dose of coal bottom ash and cow manure compost to soil Eh during plant growth is presented in Figure 1. It can be seen that Eh decreased at all treatments from the first to the $10^{\text {th }}$ week, but then increased until the $16^{\text {th }}$ week. However, the effects between treatments cannot be identified, either higher or lower. Eh decreased because during inundation the entire pore space was filled with water, so that the oxygen availability decreased and reduction process occurred. The increase at the $10^{\text {th }}$ to $16^{\text {th }}$ weeks was due to 
the plants have entered the generative phase and flooding was reduced, hence oxygen becomes more available.

The effects of bottom ash dose and cow manure compost on soil $\mathrm{pH}$ during rice plant growth is presented in Figure 2. It can be seen that soil $\mathrm{pH}$ all treatments increased from $1^{\text {st }}$ to $16^{\text {th }}$ week but insignificant. At $4^{\text {th }}$ week, soil $\mathrm{pH}$

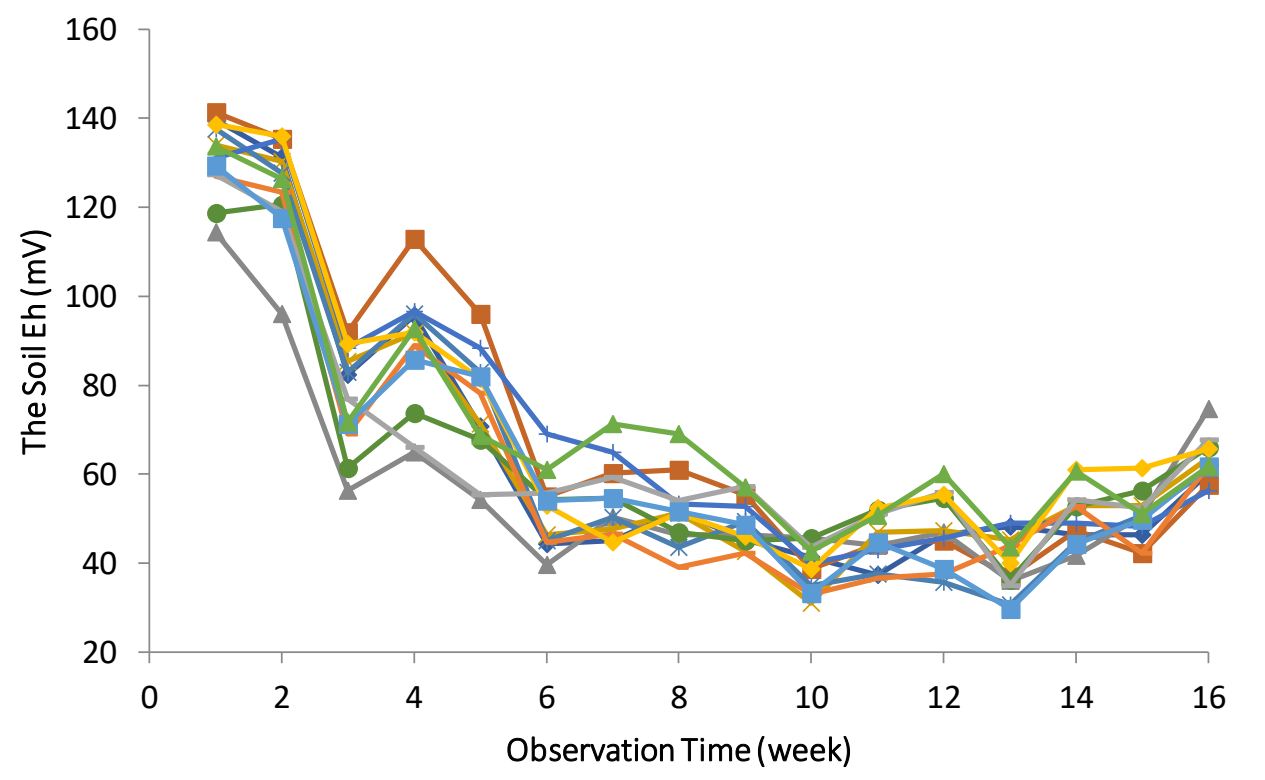

decreased due to the drainage termination, which was also shown by a relatively high increase of soil Eh. Generally soil Eh decreased (Figure 1) but soil $\mathrm{pH}$ increased during the growth (Figure 2). The increase in $\mathrm{pH}$ occurs because the reduction reaction is more dominant in consuming protons, as seen from the decrease in soil Eh during inundation.

Figure 1. Effects of bottom ash dose and cow manure compost on soil Eh. A0: bottom ash 0 tons ha-1, A1: bottom ash 1 ton ha ${ }^{-1}, \mathrm{~A} 2$ : bottom ash 2.5 tons ha ${ }^{-1}, \mathrm{~A} 3$ : bottom ash 5 tons ha- ${ }^{-1}$, K0: cow manure compost 0 tons $\mathrm{ha}^{-1}, \mathrm{~K} 1$ : cow manure compost 5 tons ha ${ }^{-1}, \mathrm{~K} 2$ : cow manure compost 10 tons ha ${ }^{-1}$.

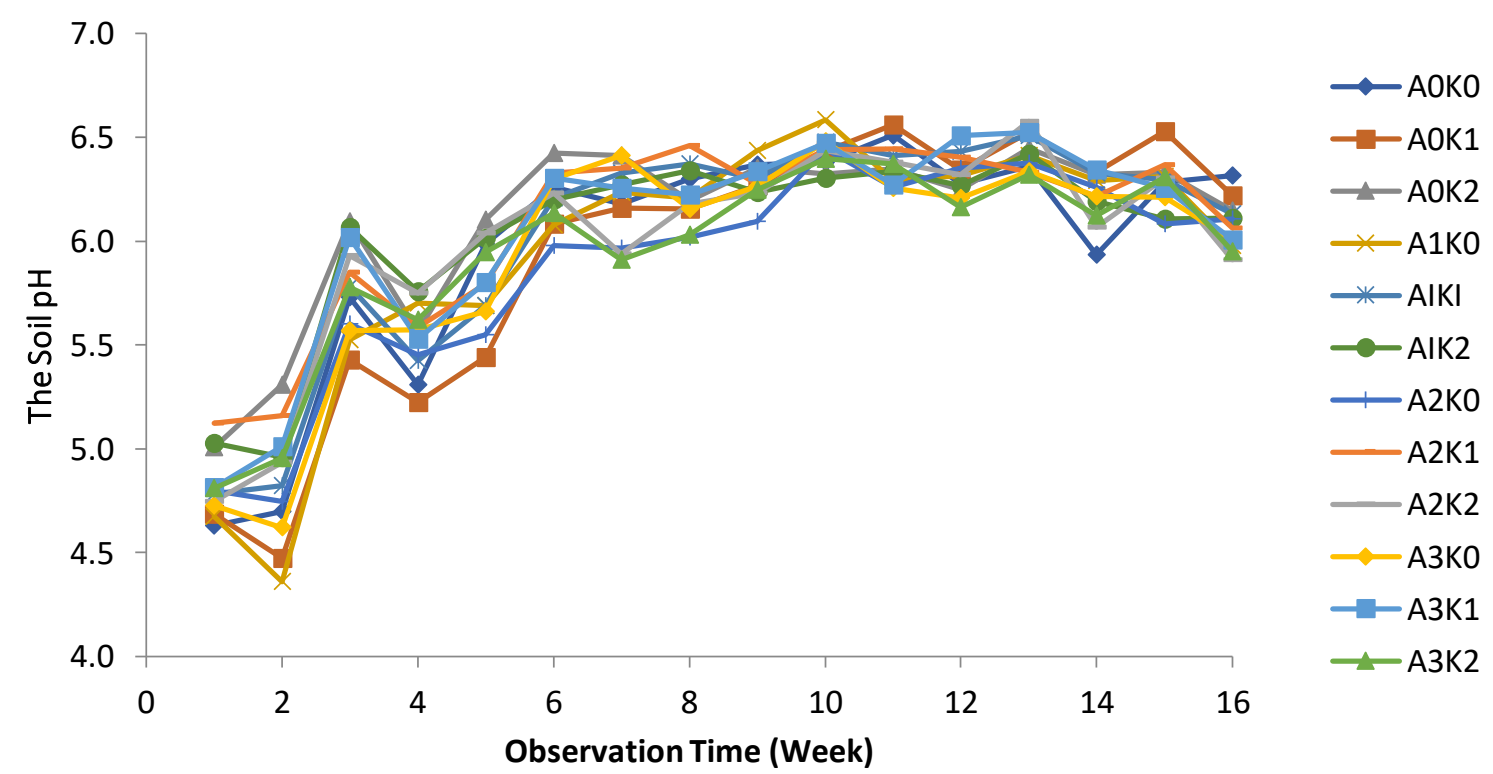

Figure 2. Effects of dose of bottom ash and cow manure compost on soil pH. A0: bottom ash 0 tons $\mathrm{ha}^{-1}, \mathrm{~A} 1$ : bottom ash 1 ton ha ${ }^{-1}, \mathrm{A2}$ : bottom ash 2.5 tons ha ${ }^{-1}, \mathrm{~A} 3$ : bottom ash 5 tons ha ${ }^{-1}, \mathrm{KO}$ : cow manure compost 0 tons ha ${ }^{-1}, \mathrm{~K} 1$ : cow manure compost 5 tons ha- ${ }^{-1}, \mathrm{~K} 2$ : cow manure compost 10 tons ha-1. 


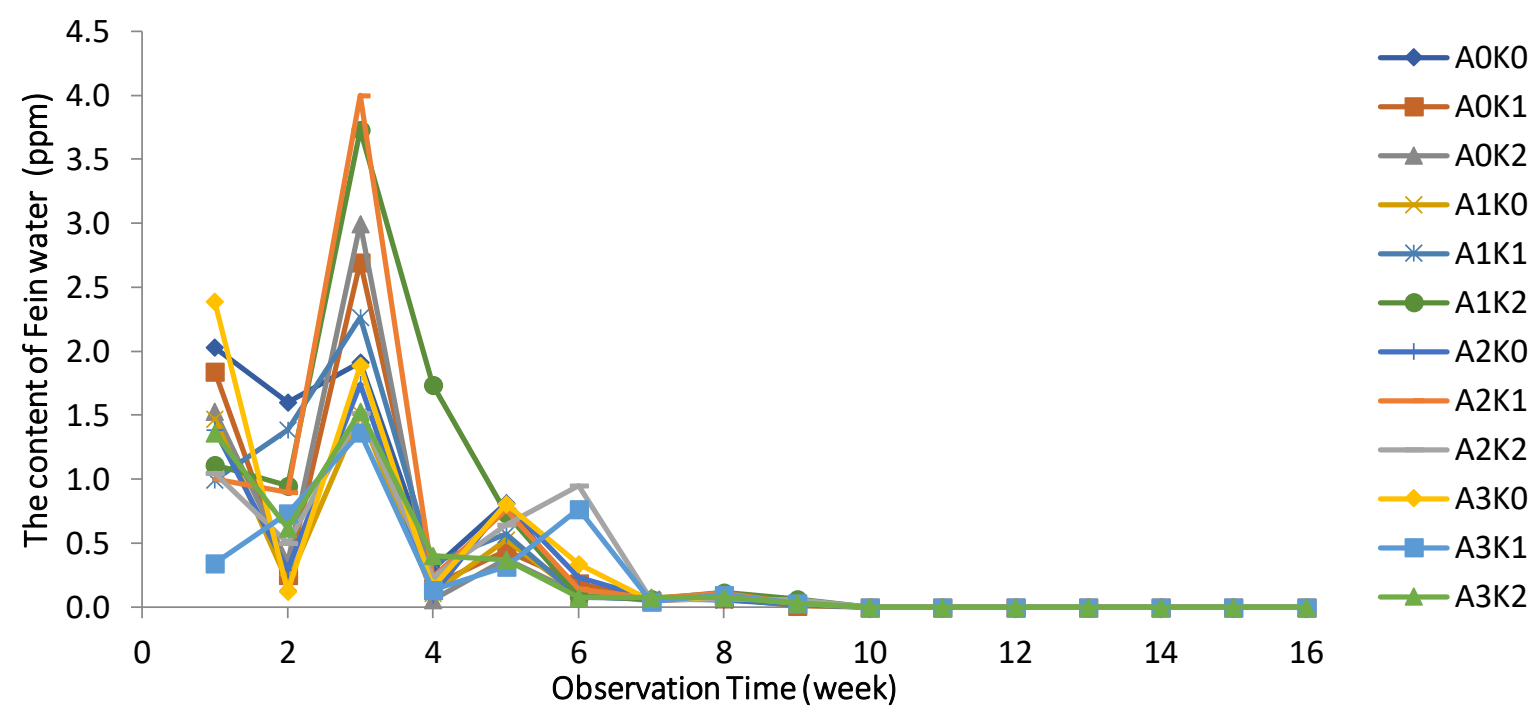

Figure 3. Effects of bottom ash dose and cow manure compost on the content of $\mathrm{Fe}$ in the drainage water. A0: bottom ash 0 tons ha ${ }^{-1}, \mathrm{~A} 1$ : bottom ash 1 ton ha ${ }^{-1}, \mathrm{~A} 2$ : bottom ash 2.5 tons ha ${ }^{-1}$, A3: bottom ash 5 tons ha- ${ }^{-1}, \mathrm{KO}$ : cow manure compost 0 tons ha ${ }^{-1}, \mathrm{~K} 1$ : cow manure compost 5 tons ha- ${ }^{-1}, \mathrm{~K} 2$ : cow manure compost 10 tons ha $^{-1}$

The effects of a dose of the bottom and cow manure compost on the content of $\mathrm{Fe}$ in drainage water during rice growth is presented in Figure 3. It can be seen that the content of content Fe in drainage water decrease related to the intermittent drainage, whereas $\mathrm{Fe}$ increased when submerged and decreased when drained. After 3 weeks, the Fe content in water was relatively stable. Water Fe was not measured again at $10^{\text {th }}$ week, but however, the effects of treatments on water Fe has not been seen until the $16^{\text {th }}$ week. The decrease in water Fe content related to the loss of the elements during a water change.

The effects of bottom ash dose and cow manure compost on the content of $\mathrm{Mn}$ in drainage water during rice growth is presented in Figure 4. It was found that the highest $\mathrm{Mn}$ content in water was $69.4 \mathrm{ppm}$, which increased from the $1^{\text {st }}$ to $2^{\text {nd }}$ week. Then decreased until the $16^{\text {th }}$ week with the highest $\mathrm{Mn}$ concentration was only $4.2 \mathrm{ppm}$ at the period, allegedly because of some element loss during a water change. However, the effect of each treatment has not been seen yet.
Fe and $\mathrm{Mn}$ contents in the drainage water decreased during submerging, which were thought due to the dilution effect. New inundated water contains more oxygen and thus the reaction was more oxidative, or at least, the formation of $\mathrm{Fe}^{2+}$ and $\mathrm{Mn}^{2+}$ can be suppressed. It also appears that $\mathrm{Fe}$ and $\mathrm{Mn}$ contents in the drainage water were smaller than in the soil (Figure 3 and 4).

The effects of bottom ash dose and cow manure compost on $\mathrm{Fe}_{\text {DTPA }}$ content in the soil during rice plant growth is presented in Figure 5. It was seen the mean $\mathrm{Fe}_{\text {DTPA }}$ content increased from 58.28 to $60 \mathrm{ppm}$ in the first week of flooding, but dropped to $55.15 \mathrm{ppm}$ at the $4^{\text {th }}$ week. That is closely related to inundation and drying process. The Fe content still fluctuated up to $16^{\text {th }}$. Inundation reduced $\mathrm{Fe}^{3+}$ to $\mathrm{Fe}^{2+}$ which dissolves easily, and vice versa during drainage. However, the effect of each treatment has not been seen yet. The Content Fe $\mathrm{P}_{\text {DTP }}$ have not been seen to increase in the first week of submerging (Figure 5). The highest $\mathrm{Fe}_{\mathrm{DTPA}}$ content was $102 \mathrm{ppm}$ occurred at week $7^{\text {th }}$ to $16^{\text {th }}$, with the average $63.25 \mathrm{ppm}$. 
The effects of bottom ash dose and cow manure compost on $\mathrm{Mn}_{\mathrm{DTPA}}$ content in the soil during plant growth is presented in Figure 6 . It showed an increase in $\mathrm{Mn}_{\mathrm{DTPA}}$ content in soil from the first week (472 $\mathrm{ppm}$ ) to week $8^{\text {th }}$ to reach $923 \mathrm{ppm}$. There was a decrease after that but until the $16^{\text {th }}$ week it was unstable, ranged from $690-858 \mathrm{ppm}$. $\mathrm{Mn}_{\text {DTPA }}$ of soil is higher than $\mathrm{Fe}_{\text {DTPA }}$ (Figure 5 and 6), because similarly with the initial condition of the soil (Table 1). In contrast, $\mathrm{Mn}_{\mathrm{DTPA}}$ content highly increased after submergence. The initial $M n_{D T P A}$ content was $372 \mathrm{ppm}$, increased up to $594 \mathrm{ppm}$ (mean) in the $1^{\text {st }}$ week, and reached the highest content at the $8^{\text {th }}$ week $(923 \mathrm{ppm})$, presented in Figure 6.

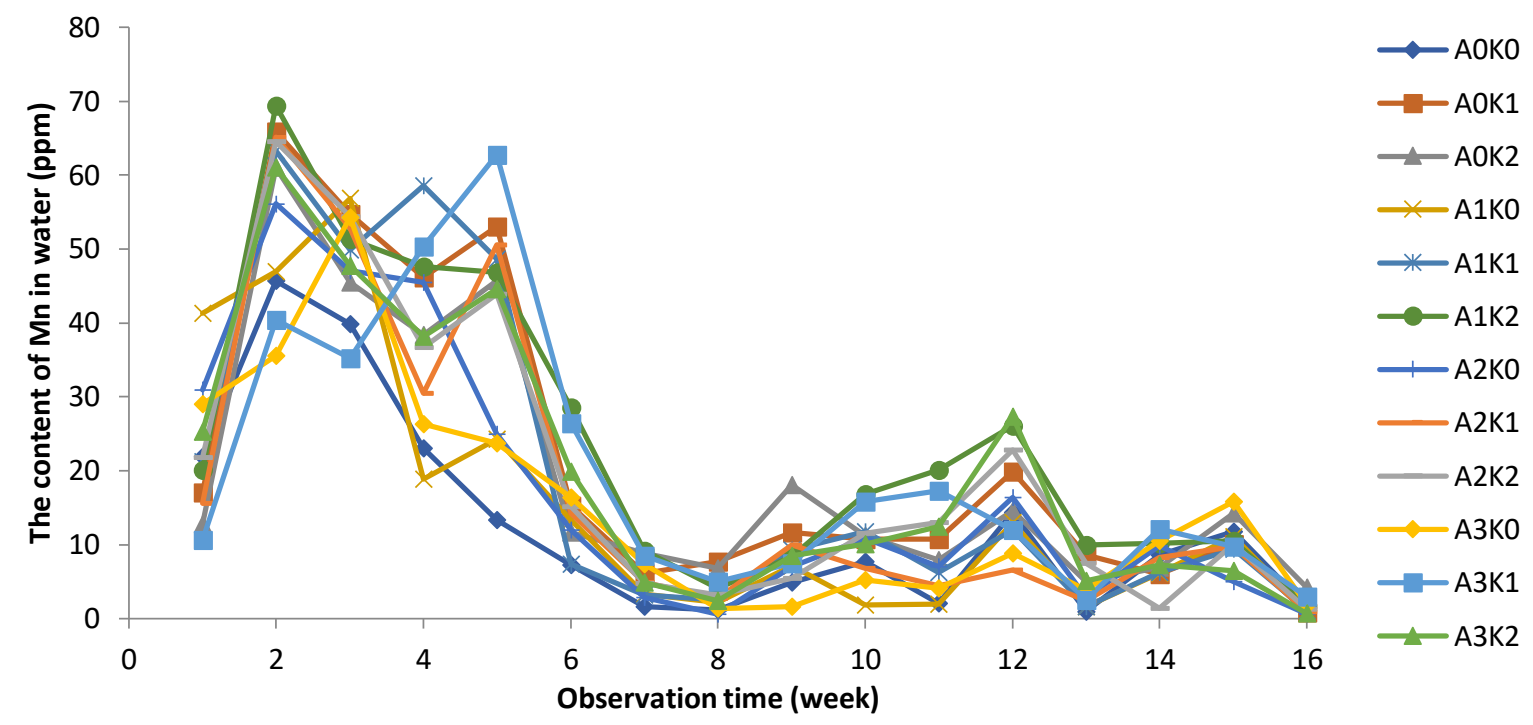

Figure 4. Effects of bottom ash dose and cow manure compost on the content of $\mathrm{Mn}$ in drainage water. A0: bottom ash 0 tons ha- ${ }^{-1}, \mathrm{~A} 1$ : bottom ash 1 ton ha ${ }^{-1}, \mathrm{~A} 2$ : bottom ash 2.5 tons ha ${ }^{-1}$, A3: bottom ash 5 tons ha- ${ }^{-1}$, KO: cow manure compost 0 tons ha- ${ }^{-1}, \mathrm{~K}$ : cow manure compost 5 tons ha- ${ }^{-1}, \mathrm{~K} 2$ : cow manure compost 10 tons ha ${ }^{-1}$

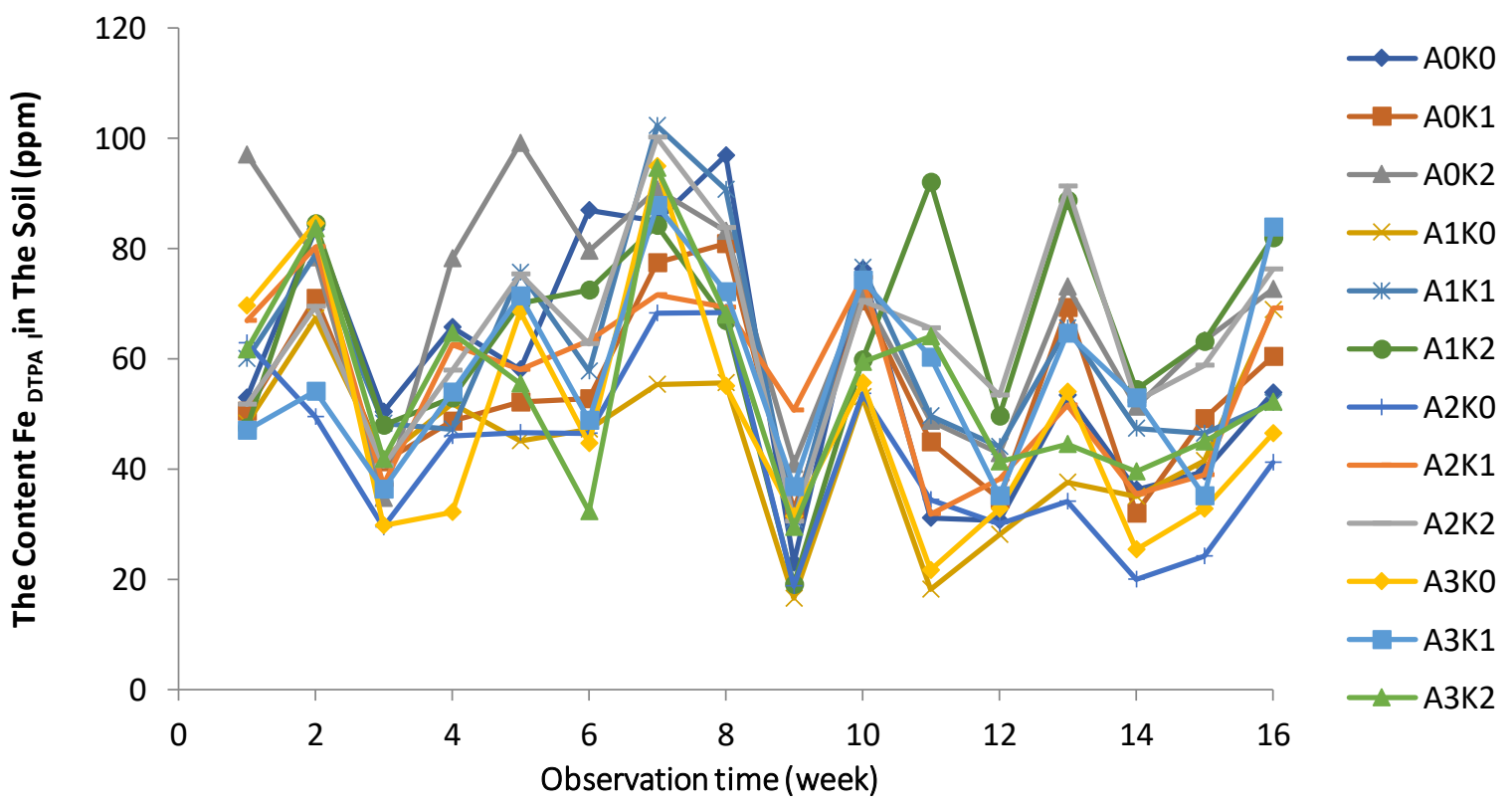

Figure 5. Effects of bottom ash dose and cow manure compost on the content Fe DTPA in the soil. A0: bottom ash 0 tons ha ${ }^{-1}, \mathrm{~A} 1$ : bottom ash 1 ton ha ${ }^{-1}, \mathrm{~A}^{2}$ : bottom ash 2.5 tons ha ${ }^{-1}, \mathrm{~A} 3$ : bottom ash 5 tons ha ${ }^{-1}$, KO: cow manure compost 0 tons ha ${ }^{-1}, \mathrm{~K}$ : cow manure compost 5 tons ha ${ }^{-1}$, $\mathrm{K} 2$ : cow manure compost 10 tons $\mathrm{ha}^{-1}$ 


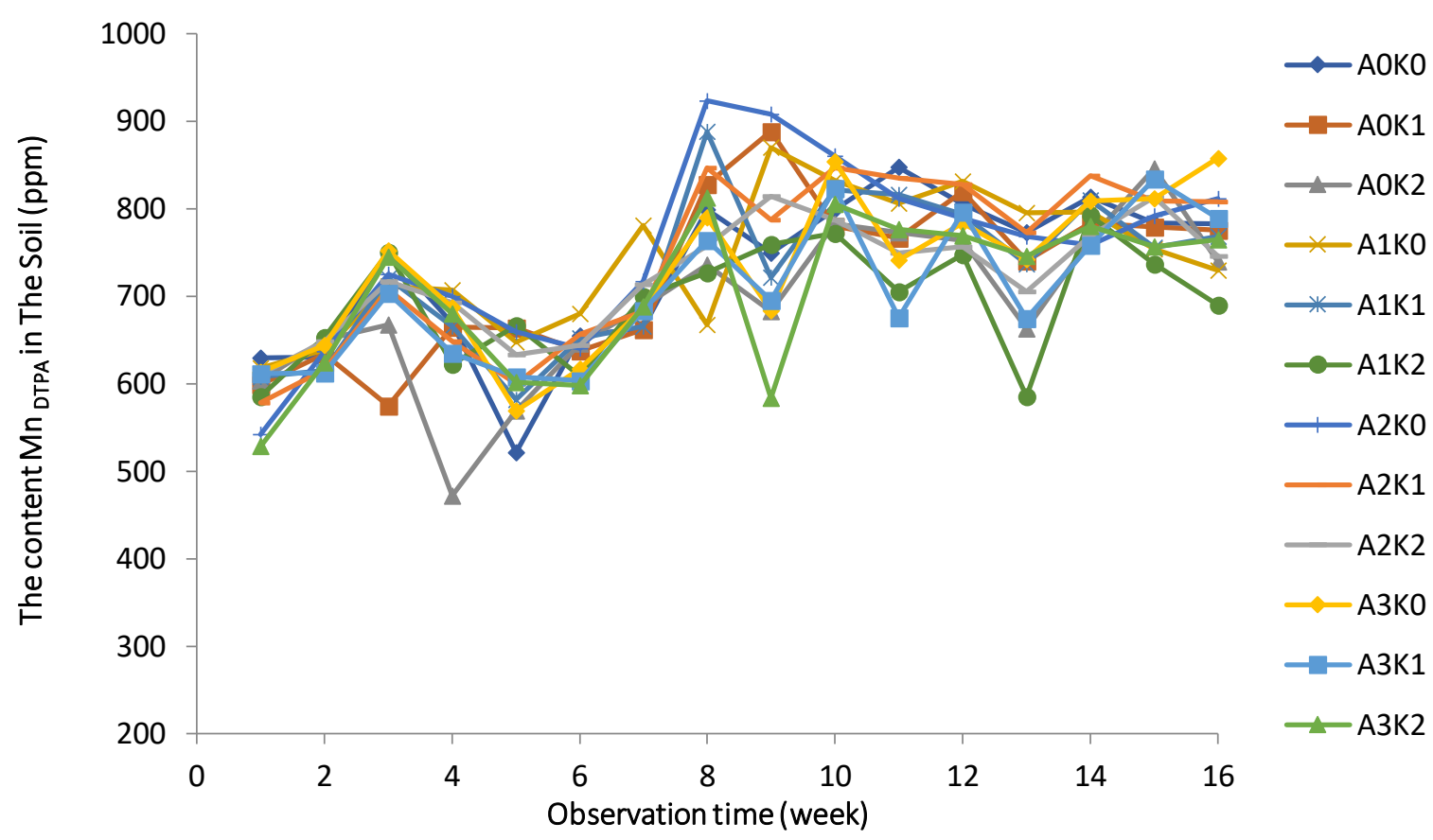

Figure 6. Effects of bottom ash dose and cow manure compost on The content $\mathrm{Mn}_{\mathrm{DTPA}}$ in the soil. A0: bottom ash 0 tons ha- ${ }^{-1}, \mathrm{~A} 1$ : bottom ash 1 ton ha- ${ }^{-1}, \mathrm{~A} 2$ : bottom ash 2.5 tons ha $^{-1}$, A3: bottom ash 5 tons ha- ${ }^{-1}$ KO: cow manure compost 0 tons ha ${ }^{-1}, \mathrm{~K} 1$ : cow manure compost 5 tons ha- ${ }^{-1}$, K2: cow manure compost 10 tons ha ${ }^{-1}$

The effects of bottom ash dose and cow manure compost on $\mathrm{Mn}_{\mathrm{DTPA}}$ content in the soil during plant growth is presented in Figure 6. It showed an increase in $\mathrm{Mn}_{\mathrm{DTPA}}$ content in soil from the first week (472 $\mathrm{ppm}$ ) to week $8^{\text {th }}$ to reach $923 \mathrm{ppm}$. There was a decrease after that but until the $16^{\text {th }}$ week it was unstable, ranged from $690-858 \mathrm{ppm}$. The initial $\mathrm{Mn}_{\mathrm{DTPA}}$ content was $372 \mathrm{ppm}$, increased up to $594 \mathrm{ppm}$ (mean) in the $1^{\text {st }}$ week, and reached the highest content at the $8^{\text {th }}$ week (923 ppm), presented in Figure 6. $\mathrm{Fe}_{\text {DTPA }}$ and $\mathrm{Mn}_{\text {DTPA }}$ in soil fluctuated at all weeks (Figure 5 and 6 ).

\section{The Effects of Bottom Ash and Cow Manure Compost on Soil Chemical Properties}

The effects of bottom ash dose and cow manure compost on soil $\mathrm{pH}, \mathrm{CEC}$, exchangeable- $\mathrm{H}, \mathrm{Fe}_{\mathrm{DTPA}}$, and $\mathrm{Mn}_{\mathrm{DTPA}}$ are presented in Table 5. Table 5 shows bottom ash dose did not significantly increase soil $\mathrm{pH}$, while cow manure compost dose significantly decreased soil pH but insignificantly improved soil CEC. Bottom ash dose insignificantly decreased exchangeable- $\mathrm{H}$, whereas cow manure significantly decreased soil exchangeable-H. The addition of bottom ash and cow manure compost did not significantly reduce $\mathrm{Fe}_{\text {DTPA }}$ and $\mathrm{Mn}_{\text {DTPA }}$. However, the Fe $\mathrm{F}_{\text {DTPA }}$ and $\mathrm{Mn}_{\mathrm{DTPA}}$ tended to decrease with the addition of a dose of bottom ash and cow manure compost. The application of cow manure compost as the organic material can reduce $\mathrm{Fe}$ and thus produces organic acids. The effects of bottom ash and cow manure compost on the exchangeable cations is presented in Table 6.

It is shown that the application of bottom insignificantly increased the exchangeable cations, but cow manure compost significantly increased exchangeable cations and all base saturation except exchangeable-Mg. The highest increase of exchangeable-Ca was under cow manure compost of 5 and 10 tons ha ${ }^{-1}$, which were 0.11 and $0.24 \mathrm{cmol}^{(+)} \mathrm{kg}^{-1}$, respectively. Meanwhile, 
base saturation increased by 0.7 and $1.7 \%$ under the same treatments, respectively. The addition of cow manure compost has been shown to increase the soil $\mathrm{pH}$, exchangeable cation $(\mathrm{K}, \mathrm{Na}, \mathrm{Ca})$, base saturation and decrease the soil exchangeable-H after harvest (Table 5 and 6).

\section{The Effects of Bottom Ash and Cow Manure Compost on Yield}

The effects of bottom ash dose and cow manure compost on rice yields, including panicle number, length, and weight; pithy rice and dry straw weight are presented in Table 7. It appears that the bottom ash insignificantly affected all yield's parameters, but the cow manure compost did. The increase of panicles number, length, and weight, pithy rice weight were in line with the increase of cow manure compost dosage, except straw dry weight. The application of 5 and 10 tons ha ${ }^{-1}$ cow manure compost increased panicle weight 3.19 and $12.37 \mathrm{~g} \mathrm{pot}^{-1}$, and straw dry weight 15.86 and $13.58 \mathrm{~g} \mathrm{pot}^{-1}$, respectively.

Table 5. Effects of Bottom Ash Dose and Cow Manure Compost on Soil pH, CEC, Exchangeable-H, $\mathrm{Fe}_{\mathrm{DTPA}}$, and $\mathrm{Mn}_{\mathrm{DTPA}}$

\begin{tabular}{|c|c|c|c|c|c|}
\hline \multirow{2}{*}{ Treatment } & \multirow{2}{*}{$\mathrm{pH}\left(\mathrm{H}_{2} \mathrm{O}\right)$} & \multirow{2}{*}{\multicolumn{2}{|c|}{$\begin{array}{l}\text { CEC Exchangeable-H } \\
--\left(\mathrm{cmol}(+) \mathrm{kg}^{-1}\right)-\end{array}$}} & $\mathrm{Fe}_{\text {DTPA }}$ & $M n_{\text {DTPA }}$ \\
\hline & & & & \multicolumn{2}{|c|}{-- (ppm)-- } \\
\hline \multicolumn{6}{|c|}{ The dose of bottom ash } \\
\hline AO & $4.51 \mathrm{a}$ & $17.09 \mathrm{a}$ & $0.23 \mathrm{a}$ & $170 \mathrm{a}$ & $700 \mathrm{a}$ \\
\hline A1 & $4.51 \mathrm{a}$ & $17.73 \mathrm{a}$ & $0.27 a$ & $188 \mathrm{a}$ & $666 \mathrm{a}$ \\
\hline$A 2$ & $4.52 \mathrm{a}$ & $17.67 \mathrm{a}$ & $0.28 \mathrm{a}$ & $140 \mathrm{a}$ & $673 a$ \\
\hline A3 & $4.53 a$ & $17.09 \mathrm{a}$ & $0.27 a$ & $144 \mathrm{a}$ & $668 a$ \\
\hline \multicolumn{6}{|c|}{ The dose of cow manure compost } \\
\hline KO & $4.57 \mathrm{a}$ & $17.17 \mathrm{a}$ & $0.32 \mathrm{a}$ & $172 \mathrm{a}$ & $672 \mathrm{a}$ \\
\hline K1 & $4.52 \mathrm{~b}$ & $17.51 \mathrm{a}$ & $0.27 a b$ & $168 \mathrm{a}$ & $676 a$ \\
\hline K2 & $4.45 c$ & $17.54 \mathrm{a}$ & $0.19 \mathrm{~b}$ & $141 \mathrm{a}$ & $683 a$ \\
\hline
\end{tabular}

Remarks: Mean with different letter are significantly different at $\mathrm{P}<0.05$ using a DMRT test. A0: bottom ash 0 tons $\mathrm{ha}^{-1}, \mathrm{~A} 1$ : bottom ash 1 ton ha- ${ }^{-1}, \mathrm{A2}$ : bottom ash 2.5 tons ha- ${ }^{-1}, \mathrm{~A} 3$ : bottom ash 5 tons ha ${ }^{-1}, \mathrm{KO}$ : cow manure

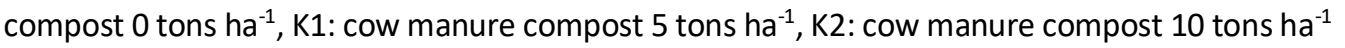

Table 6. Effects of Bottom Ash Dose and Cow Manure Compost on Exchangeable Cations and Base Saturation

\begin{tabular}{|c|c|c|c|c|c|}
\hline \multirow[b]{2}{*}{ Treatment } & \multicolumn{4}{|c|}{ Exchangeable } & \multirow{2}{*}{$\begin{array}{c}\text { Base saturatior } \\
\text { (\%) }\end{array}$} \\
\hline & $-K$ & $-\mathrm{Na}$ & $-\mathrm{Ca}$ & $-M g$ & \\
\hline \multicolumn{6}{|c|}{ The dose of bottom ash } \\
\hline AO & $0.26 a$ & $0.15 a$ & $1.75 \mathrm{a}$ & $0.39 a$ & $14.97 \mathrm{a}$ \\
\hline A1 & $0.26 \mathrm{a}$ & $0.15 \mathrm{a}$ & $1.88 \mathrm{a}$ & $0.40 a$ & $15.15 \mathrm{a}$ \\
\hline$A 2$ & $0.25 a$ & $0.13 \mathrm{a}$ & $1.84 \mathrm{a}$ & $0.43 a$ & $15.11 \mathrm{a}$ \\
\hline A3 & $0.25 a$ & $0.14 \mathrm{a}$ & $1.74 \mathrm{a}$ & $0.40 a$ & $14.81 \mathrm{a}$ \\
\hline \multicolumn{6}{|c|}{ The dose of cow manure compost } \\
\hline KO & $0.23 a$ & $0.13 \mathrm{a}$ & $1.69 \mathrm{a}$ & $0.39 a$ & $14.24 \mathrm{a}$ \\
\hline K1 & $0.27 \mathrm{~b}$ & $0.14 a b$ & $1.80 \mathrm{ab}$ & $0.40 a$ & $14.94 a b$ \\
\hline K2 & $0.27 \mathrm{~b}$ & $0.16 \mathrm{~b}$ & $1.93 \mathrm{~b}$ & $0.43 a$ & $15.94 \mathrm{~b}$ \\
\hline
\end{tabular}

Remarks: Mean with different letter are significantly different at $\mathrm{P}<0.05$ using a DMRT test. A0: bottom ash 0 tons $\mathrm{ha}^{-1}$, A1: bottom ash 1 ton ha- ${ }^{-1}$, A2: bottom ash 2.5 tons ha- ${ }^{-1}$, A3: bottom ash 5 tons ha ${ }^{-1}$, KO: cow manure

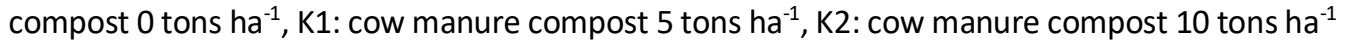


Nurmegawati et al. / SAINS TANAH - Journal of Soil Science and Agroclimatology, 16(1), 2019, 10

Table 7. Effects of Bottom Ash Dose and Cow Manure Compost on Rice Yield

\begin{tabular}{|c|c|c|c|c|c|}
\hline Treatment & $\begin{array}{c}\text { Panicle number } \\
\text { (strands) }\end{array}$ & $\begin{array}{l}\text { Panicle length } \\
\text { (cm) }\end{array}$ & $\begin{array}{c}\begin{array}{c}\text { Panicle weight } \\
\text { (grams) }\end{array} \\
\end{array}$ & $\begin{array}{l}\text { Pithy rice weight } \\
\text { (grams) }\end{array}$ & $\begin{array}{c}\text { Dry straw weight } \\
\text { (grams) }\end{array}$ \\
\hline \multicolumn{6}{|c|}{ The dose of bottom ash } \\
\hline AO & $9.33 a$ & $18.52 \mathrm{a}$ & 9.32 a & $5.40 \mathrm{a}$ & $19.07 \mathrm{a}$ \\
\hline A1 & $9.56 \mathrm{a}$ & $18.77 \mathrm{a}$ & $10.73 \mathrm{a}$ & $6.60 \mathrm{a}$ & $18.36 \mathrm{a}$ \\
\hline A2 & $8.67 \mathrm{a}$ & $19.12 \mathrm{a}$ & 10.19 a & $6.30 \mathrm{a}$ & $17.50 \mathrm{a}$ \\
\hline A3 & $9.67 a$ & $18.38 \mathrm{a}$ & $9.00 \mathrm{a}$ & $5.00 \mathrm{a}$ & $16.10 \mathrm{a}$ \\
\hline \multicolumn{6}{|c|}{ The dose of cow manure compost } \\
\hline KO & $6.75 a$ & $17.36 \mathrm{a}$ & $4.63 \mathrm{a}$ & $2.40 \mathrm{a}$ & $11.27 \mathrm{a}$ \\
\hline K1 & $9.08 \mathrm{~b}$ & $18.24 \mathrm{a}$ & $7.82 \mathrm{a}$ & $4.57 \mathrm{a}$ & $27.13 b$ \\
\hline K2 & $12.08 \mathrm{c}$ & $20.49 \mathrm{~b}$ & $17.00 \mathrm{~b}$ & $10.50 \mathrm{~b}$ & $24.85 \mathrm{c}$ \\
\hline
\end{tabular}

Remarks: Mean with different letter are significantly different at $\mathrm{P}<0.05$ using a DMRT test. A0: bottom ash 0 tons ha-1, A1: bottom ash 1 ton ha- ${ }^{-1}, \mathrm{~A} 2$ : bottom ash 2.5 tons ha- ${ }^{-1}, \mathrm{~A} 3$ : bottom ash 5 tons ha- ${ }^{-1}$ K0: cow

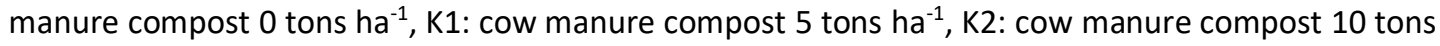
$\mathrm{ha}^{-1}$

\section{DISCUSSION}

The addition of bottom ash and cow manure compost on the new-established paddy field generally decreased soil Fe $\mathrm{ETPA}_{\text {and }}$ and $\mathrm{Mn}_{\text {DTPA }}$ (Table 5) but not significant, because these two elements are strongly influenced by soil $\mathrm{pH}$. This was supported by Cyio (2008) which states that changes in soil Eh and $\mathrm{pH}$ are affected by nutrients solubility and availability, as well as their transformation. According to the Eh-pH diagram (Krauskopf, 1979), the Mn content in this study would continue to dissolve during inundation because it is not stable compared to Fe. However, the Mn DTPA of soil is higher than $\mathrm{Fe}_{\text {DTPA }}$ because similarly with the initial condition of the soil (Table 1). Redman \& Patrick Jr. (1965) reported that after flooding for 30 days and the addition of $\mathrm{Mn}$, the mobilization of organic matter increased sharply from 159.4 to 1,730 ppm. Hassett \& Banwart (1992) state that $\mathrm{Mn}$ was an unstable element under an oxidation-reduction condition in the soil solution. Millaleo et al. (2010) added that the bioavailability of soil Mn was influenced by $\mathrm{pH}$ and redox potential. Furthermore, Porter et al. (2004) reported that changes in soil $\mathrm{pH}$ and redox potential (Eh) will affect the Mn solubility and toxicity for plants on soils with high $\mathrm{Mn}$.
Changes in soil redox potential and $\mathrm{pH}$ affect the active $\mathrm{Fe}$ in the soil solution. Based on the diagram shown by Bohn \& O'connor (1979), $\mathrm{FeOOH}$ will dissolve into $\mathrm{Fe}^{2+}$ at a specific Eh and $\mathrm{pH}$ under moderate acidity conditions, while $\mathrm{Fe}^{3+}$ will predominate under very oxidative conditions with $\mathrm{Eh}>400 \mathrm{mV}$ and $\mathrm{pH}<2$. Since Figures 1 and 2 show that the average Eh and $\mathrm{pH}$ during the study were 65 $\mathrm{mV}$ and 6 respectively, hence the dominant iron compound was $\mathrm{Fe}^{2+}$. According to the calculation of Fe content in water during rice growth (calculation was based on the results of the solubility times $\left[\mathrm{Fe}^{3+}\right]\left[\mathrm{OH}^{-}\right]^{3}=10^{-38}$ ), this indicates that $\mathrm{Fe}^{2+}$ was always more dominant than $\mathrm{Fe}^{3+}$. The highest $\mathrm{Fe}^{2+}$ content was $4 \mathrm{ppm}$, but $\mathrm{Fe}^{3+}$ was only $2.8 \times 10^{-13}$, hence there was no chance of iron poisoning. This is supported by Sulaiman at al. (1997) that the critical limit of toxicity to the soil was 260 ppm. Herviyanti \& Asmar (2005) which reported that soil $\mathrm{Fe}^{2+}$ content ranged from 126.67 - 305.30 ppm, after flooding for 30 days and extracted with 1 $\mathrm{M} \mathrm{CH}_{3} \mathrm{COOHNa} \mathrm{pH} 2.8$ at Ultisols treated with a polysaccharide.

Furthermore, the addition of bottom ash alone did not affect all the soil chemical parameters, while the addition of cow manure compost alone has been shown to increase the 
soil $\mathrm{pH}$, exchangeable cation ( $\mathrm{K}, \mathrm{Na}, \mathrm{Ca})$, base saturation and decrease the soil exchangeable$\mathrm{H}$ after harvest (Table 5 and 6 ). Simanungkalit et al. (2006) explained that the general characteristics of compost which contain nutrients in types and quantities vary depending on the original material, provide nutrients slowly (slow release) and in limited quantities, and have the main function of improving soil fertility. The increased $\mathrm{pH}$ was due to the contribution of $\mathrm{OH}^{-}$ions released by organic materials. The addition cow manure compost as organic material could increase the exchangeable alkaline cations such as $\mathrm{K}, \mathrm{Ca}$ and $\mathrm{Na}$ (Table 6) which can bind and release these elements. 5 and 10 tons ha ${ }^{-1}$ of cow manure compost increased exchangeable-Ca by 0.11 and $0.24 \mathrm{cmol}^{(+)} \mathrm{kg}^{-1}$, and base saturation by 0.7 and $1.7 \%$, respectively. Munawar (2011) states that the ability of organic matter to interact with positively charged ions makes nutrients easily available to plants. Furthermore, applying cow manure compost can reduce exchangeable-Fe, and this was supported by Tan (1998) which state organic compounds in acid soils will affect metal fractions so that metals availability decreases.

The interaction of bottom ash and cow manure compost addition did not affect the paddy yield, but only the addition of cow manure compost increased the panicles number, length, and weight, pithy rice weight (Table 7). Meanwhile, the addition of bottom ash alone did not affect the yield. According to Herviyanti \& Asmar (2005), 225 ppm of the non-ionic organic compound (polysaccharide) in new-established rice field increased grain weight by $2.95 \mathrm{~g} \mathrm{pot}^{-1}$ and pithy rice by $35 \%$. The plants were thought to experiencing $\mathrm{Mn}$ toxicity since the soil $\mathrm{Mn}_{\mathrm{DTPA}}$ was higher than

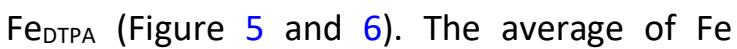
content during this study was $60 \mathrm{ppm}$, and hence Fe toxicity has not occurred (critical limit $=260$ ppm, Sulaiman et al., 1997), but Mn toxicity was taken place since its mean content was of $600 \mathrm{ppm}$ (critical limit=15-60 ppm, (Black, 1968)). This is supported by Jugsujinda \& Patrick Jr. (1993) stating that rice plants would have the $\mathrm{Fe}$ and $\mathrm{Mn}$ toxicity if exceeding the threshold, 2.500 ppm for Fe and 300 ppm for Mn. Tanaka \& Navasero (1966) added that there was an antagonistic reaction in the absorption of these elements, the symptoms of iron toxicity and manganese deficiency differ.

\section{CONCLUSION}

The addition of bottom ash and cow manure compost at the dosage in this study was not able to reduce the levels of Fe $\mathrm{E}_{\mathrm{DTPA}}$ and $\mathrm{Mn}_{\text {DTPA }}$ at newly established rice fields. However, the application of cow manure compost significantly increased soil $\mathrm{pH}$, exchangeable cation ( $\mathrm{K}, \mathrm{Na}, \mathrm{Ca})$, base saturation and decreased exchangeable- $\mathrm{H}$. The addition of bottom ash does not affect paddy yield, while cow manure compost up to 10 tons $\mathrm{ha}^{-1}$ increased panicle and straw dry weight.

\section{REFERENCES}

Agustini, R. . (2016). Respon tanah mineral masam dan tanaman caisim (Brassica juncea) terhadap pemberian abu dasar (bottom ash) dan kompos kotoran sapi sebagai amelioran tanah. Bogor Agricultural University.

Black, C. (1968). Soil-plant Relationship. New Delhi, India: Wiley Eastern (Put.) Ltd.

Bohn, H. . M., \& G.A O'connor. (1979). Soil Chermistry. New York.: A Wiley Inter Sci. Publ. Jhon Wiley and Sons.

Cyio, M. B. (2008). Efektivitas Bahan Organik dan Tinggi Genangan terhadap Perubahan Eh , pH , dan Status Fe , P , Al Terlarut pada Tanah Ultisol. J. Agroland, 15(4), 257-263.

Hartatik, W., Sulaeman, \& Kasno, A. (2010). Perubahan Sifat Kimia Tanah dan Ameliorasi Sawah Bukaan Baru. Di dalam: Editor. Edisi kedua.. Bogor. hlm. In F. Agus, Wahyunto, \& D. Santo (Eds.), Tanah sawah bukaan baru. 
(pp. 53-76). Bogor: Balai Besar Litbang Sumberdaya Lahan Pertanian.

Hassett, J. ., \& Banwart, W. . (1992). Soils and Their Enviroment. New Jersey: Prentice Hall.

Herviyanti \& Asmar. (2005). Potensi senyawa organik tidak ter-ion dalam mengurangi kelarutan besi (Fe) untuk meningkatkan produktifitas tanah sawah bukaan baru. J. Solum, 2(1), 40-49.

Herviyanti, Prasetyo, T. B., Ahmad, F., \& Harianti, M. (2011). Upaya Mengendalikan Keracunan Besi ( Fe ) dengan Bahan Humat dari Kompos Jerami Padi dan Pengelolaan Air untuk Meningkatkan Produktivitas Lahan Sawah Bukaan Baru di Situng, Sumatera Barat. Tanah Dan Iklim, 34, 40-47.

Iskandar, Suwardi, \& Ramadina, E. (2008). Pemanfaatan bahan ameliorant abu terbang pada lingkungan gambut: (1) Pelepasan hara makro. Journal Tanah Indonesia, 1(1), 1-6.

James, A. K., Thring, R. W., Helle, S., \& Ghuman, H. S. (2012). Ash Management ReviewApplications of Biomass Bottom Ash. Energies, $\quad 5$, 3856-3873. https://doi.org/10.3390/en5103856

Jugsujinda, A., \& Patrick Jr, W. H. (1993). Evaluation of toxic conditions associated with oranging symptoms of rice in a flooded Oxisols in Sumatra, Indonesia. Plant and Soil. Plant and Soil, 152(2), 237-243.

Krauskopf, K. B. (1979). Krauskopi. K.B. 1979. Introduction to Geochemistry. International Student Edision. (Internatio). Tokyo: McGRAW-Hill Kogakusha, LTD.

Millaleo, R., Rayes-Diaz, M., Ivanov, A. G., Mora, M. L., \& Alberdi, M. (2010). Manganese as Essential and Toxic Element for Plants: Transport, Accumulation and Resistance Mechanisms. J. Soil Sci. Plant Nutr., 10(4), 476-494.

Munawar, A. (2011). Kesuburan Tanah dan Nutrisi Tanaman. (A. Munawar, Ed.). Bogor: IPB Press.

Nursyamsi, D., Setyorini, D., \& Adiningsih, J. S. (1996). Pengelolaan hara dan pengaturan drainase untuk menanggulangi kendala produktivitas sawah baru. In Prosiding
Pertemuan Pembahasan dan Komunikasi Hasil Penelitian Tanah dan Agroklimat (pp. 113-128). Bogor (ID): Pusat Penelitian Tanah dan Agroklimat.

Park, N. D., Rutherford, P. M., Thring, R. W., \& Helle, S. S. (2012). Chemosphere Wood pellet fly ash and bottom ash as an effective liming agent and nutrient source for rye grass ( Lolium perenne L.) and oats ( Avena sativa ). Chemosphere, 86, 427-432. https://doi.org/10.1016/j.chemosphere. 2011.10.052

Porter, G. ., Bajita-Locke, J. B., Hue, N. V., \& Strand, D. (2004). Mangananese solubility and phytotoxicity affaected by soil moisture, oxygen level and green manure addition. Communications in Soil Science and Plant Analysis, 35(1-2), 99-116.

Redman, F. H., \& Patrick Jr, W. H. (1965). Effect of submergence on several biological and chemical soil properties (Bulletin N). Louisiana: Louisiana State University and Agriculture and Mechanical College.

Sell, N., Mclntosh, T., Severance, C., \& Peterson, A. (1989). The agronomic landspreading of coal bottom ash: using a regulated soil waste as a resource. Resources, Conservation and Recycling, 2(2), 119-129.

Simanungkalit, R. D. ., Suriadikarta, D. ., Saraswati, R., Setyorini, D., \& Hartatik, W. (2006). Pupuk Organik dan Pupuk Hayati. Bogor (ID): Balai Besar Penelitian dan Pengembangan Sumberdaya Lahan Pertanian.

Sulaiman, A., Arifin, \& Nohoi, G. (1997). Studi korelasi pertumbuhan tanaman padi dengan besi tanah. J. Kalimantan Agrikultura, 2(4), 1-14.

Tan, K. H. (1998). Dasar-dasar kimia tanah. Yogyakarta: Gadjah Mada University Press.

Tanaka, A., \& Navasero, S. A. (1966). Soil Science and Plant Nutrition Interaction between iron and manganese in the rice plant. Soil Science and Plant Nutrition, 12(5), 29-33. https://doi.org/10.1080/00380768.1966. 10431958

Utami, S. N. ., \& Handayani, S. (2003). Sifat Kimia Entisol pada Sistem Pertanian Organik. Ilmu Pertanian, 10(2), 63-69. 